\title{
Urinary kallikrein activity of workers exposed to lead
}

\author{
P. Boscolo, G. Porcelli, G. CECChetti, E. SAlimei, AND \\ A. IANNACCONE \\ From the Istituti di Medicina del Lavoro e di Chimica dell'Università Cattolica di Roma, Centro di \\ Chimica Recettori del CNR, ENPI
}

ABSTRACT Two groups of men of different age ranges and with the same period of lead exposure were selected for study in a recently opened car-battery factory. Two other groups of age-matched men, not exposed to heavy metals in their work, were used as controls. Morning urines were collected from control and exposed groups for determination of urinary kallikrein activity, urinary $\delta$-aminolevulinic acid (ALA) and lead levels. The environmental lead levels and the urinary ALA and lead values indicated that exposure in the factory was not heavy. The older group of lead-exposed workers showed greatly reduced urinary kallikrein activity compared with that of the age-matched controls. In contrast, the younger group did not show any significant alteration in urinary kallikrein excretion.

Lead has a strong affinity for biochemical ligands. Consequently it may act on enzymes, displacing their essential metals (Finelli et al., 1974), modifying their synthesis (Rhyne and Goyer, 1971) and blocking their interaction with the substrate (Iannaccone $e t$ al., 1974a). These biochemical alterations induce changes in the structure of mitochondria and endoplasmic reticulum in the kidney of exposed animals (Galle and Morel-Maroger, 1965; Boscolo et al., 1977a) and humans (Galle and Morel-Maroger, 1965; Cramér et al., 1974). There may be many stages in the response of human kidney to chronic lead exposure; intranuclear inclusion bodies seem to be present only in the first of them (Cramér et al., 1974).

A study by Dingwall-Fordyce and Lane (1963) reported that pensioners, who had been heavily exposed to lead in a battery factory, suffered a great number of deaths attributable to cerebrovascular catastrophes. Unfortunately this investigation did not yield information about the incidence of nephropathy or hypertension in these pensioners. However, other studies (Lane, 1949; Lilis et al., 1968) demonstrated that lead may induce renal disease and high blood pressure in workers exposed to the metal under conditions which were not clearly defined. Only workers in carefully supervised plants (although

Received for publication 30 November 1977 Accepted for publication 18 January 1978 absorbing more lead than the unexposed population) escape the risk of nephropathy or vascular alterations (Cramér and Dahlberg, 1966).

Sandstead et al. (1970) have reported a decrease in plasma renin activity and in aldosterone secretion rate in nine lead-intoxicated patients (one of them hypertensive). Our unpublished study shows that plasma renin activity may be either low or excessive in lead workers without symptoms of poisoning, while it seems to be reduced in lead-exposed subjects with hypertension or nephropathy. This suggests that hypertension induced by lead may not depend on an increase of a vasopressor enzyme such as renin, but on a decrease of a vasodilator substance such as kallikrein.

It has been demonstrated that urinary kallikrein excretion is decreased in patients with essential hypertension (Margolius et al., 1971; Greco et al., 1974; Croxatto et al., 1974), while it seems to be unaltered in patients suffering from renal hypertension. Reduced levels of urinary kallikrein activity were also found in members of families with high blood pressure (Zinner et al., 1976).

Urinary kallikrein is an enzyme which seems to be synthesised in the kidney only (Croxatto et al., 1974; Nustad et al., 1975). It releases bradykinin, a potent vasodilator polypeptide, from an $\alpha_{2}$ plasma globulin, kininogen. The synthesis of this enzyme is related to its excretion in the urine (Roblero et al., 1973). However, it is still not clear whether renal kallikrein acts 
on the kidney only, or can also pass into the vessels, acting in the periphery of the vascular system (Croxatto et al., 1974). Renal kallikrein seems also to reinforce the vasodilator action of prostaglandins (McGiff et al., 1976) and, with other hormones, to regulate sodium excretion (Margolius et al., 1974).

In 1972 we determined the urinary kallikrein activity in 24-hour urines of lead-exposed workers admitted as inpatients to the Institute of Occupational Medicine of the Catholic University of Rome, in order to establish the diagnosis of lead poisoning (Iannaccone et al., 1974b; Iannaccone et al., 1975). We also made a preliminary study of the urinary kallikrein excretion of lead-treated rabbits (Iannaccone et al., 1974b). Since 1974 we have been monitoring urinary kallikrein activity in morning urines of workers exposed to lead in a car-battery factory. In March 1974 the urinary kallikrein activity of exposed workers was very low; in September 1975, after some environmental improvements, the urinary kallikrein excretion of the same workers (still remaining lower than that of a control group) was found to have increased (Boscolo et al., 1977b). In June 1977, after a further reduction of the lead in the air of the factory, we determined the urinary kallikrein activity of two groups of workers of different ages but with the same period of lead exposure.

\section{Subjects and methods}

We studied lead workers in a car-battery factory set in a village near Frosinone, 50 miles from Rome. The factory, a small branch of a company in the north of Italy, started production in 1968. Until 1972 there were two separate working rooms. From 1972 to 1974 the capacity of the plant increased and the workers were then situated in four different departments. In 1974 the lead concentration in the air of the factory was high; corrective measures were subsequently taken to improve the air quality, as reported in a previous study (Boscolo et al., 1977b). From 1975 to 1977 the operations involving hazardous lead exposure were isolated and workers employed in such processes used personal protective devices. Table 1 shows the concentration of lead in the air and the

Table 1 Lead in the air of a factory making car batteries

\begin{tabular}{llll}
\hline Sampling site & $\begin{array}{l}\text { No. of } \\
\text { workers }\end{array}$ & \multicolumn{2}{l}{ Lead in air $\left(\mu \mathrm{g} / \mathrm{m}^{3}\right)$} \\
\cline { 3 - 4 } & & Mean & Range \\
\hline Assembling & 36 & 20 & $16-22$ \\
Welding & 28 & 45 & $21-67$ \\
Plate-spreading & 17 & 33 & $24-53$ \\
Foundry & 10 & 66 & $50-100$ \\
\hline
\end{tabular}

*Excluding 15 workers assigned to cleaning and maintenance. number of workers near the sampling sites of each department. The environmental lead levels were determined by filtering the dust on micropore membranes (according to the Italian law n. 615) and by atomic absorption and $x$-ray fluorescence analysis (Cecchetti et al., 1969).

In 1968, 66 men were employed in the factory. From 1972 to 1974 additional men were employed, to a final total of 106. From 1972 the plant was supervised by the Ente Nazionale Previdenza Infortuni (ENPI) in collaboration with the Catholic University of Rome. Since 1972 workers, alerted to potential occupational hazards, were forbidden to smoke or eat in the factory. Suggestions from personnel were also taken into consideration in improving the environment of the workplaces and in the use of personal protective devices.

From 1972 to 1974 ten workers, who suffered from headache, bad taste in the mouth, constipation and mild abdominal pain, were admitted to the Institute of Occupational Medicine of the Catholic University of Rome to establish the diagnosis of lead poisoning, but clinical examination showed no evidence of this. However, the workers' urinary ALA and lead levels (determined before and during EDTA treatment) were altered. These subjects, and three other workers suffering from labile hypertension and showing reduced urinary kallikrein activity, were suspended from the factory for several months and no longer exposed to heavy concentrations of lead. In June 1977 personnel were in good health except for a few subjects suffering from gastric ulcer.

For our study we selected 90 men who had been exposed to lead in the factory for more than three years, and who had not suffered symptoms of poisoning and had not been treated previously with EDTA. All these subjects had frequently changed their workplaces in their department; 43 had changed departments in the last three years, 19 remained at the assembling station, 14 at welding, two at platespreading, two at the foundry and ten were assigned to cleaning and maintenance of the factory. These men were divided into two groups of 45 subjects ranging from 22 to 32 years and from 34 to 54 years of age. We randomly selected 23 young workers from the first group and matched them with another 23 older workers of the second group representing the same duration of lead exposure. The exposure of both groups was $4 \cdot 1 \pm 0 \cdot 1$ years (mean $\pm \mathrm{SE}$ ). The age of the younger group was $27.5 \pm 0.5$ years (mean \pm SE) and that of the older group was $41 \cdot 1 \pm$ $1 \cdot 2$ years.

For each exposed man we selected an agematched control from the workers of another factory situated in the suburbs of Rome; these were mostly 'blue collar' workers and had not been exposed to 
Table 2 Kallikrein activity, ALA and lead in morning urine of lead-exposed workers

\begin{tabular}{|c|c|c|c|c|c|c|c|c|c|}
\hline \multirow[t]{2}{*}{ Test } & \multirow{2}{*}{$\begin{array}{l}\text { Age } \\
\text { (years) }\end{array}$} & \multicolumn{3}{|c|}{ Control } & \multicolumn{3}{|c|}{ Exposed } & \multirow[t]{2}{*}{$\mathbf{t}$} & \multirow[t]{2}{*}{$\boldsymbol{P}$} \\
\hline & & No. & Mean & $S E$ & No. & Mean & $S E$ & & \\
\hline Kallikrein (units/g creatinine) & $\begin{array}{l}22-32 \\
34-52\end{array}$ & $\begin{array}{l}23 \\
23\end{array}$ & $\begin{array}{l}16 \cdot 53 \\
14 \cdot 78\end{array}$ & $\begin{array}{l}1 \cdot 94 \\
1 \cdot 24\end{array}$ & $\begin{array}{l}23 \\
23\end{array}$ & $\begin{array}{r}13 \cdot 24 \\
6 \cdot 38\end{array}$ & $\begin{array}{l}1.95 \\
1.45\end{array}$ & $\begin{array}{l}1 \cdot 195 \\
4 \cdot 394\end{array}$ & $\begin{array}{l}>0.05 \\
<0.001\end{array}$ \\
\hline ALA (mg/g creatinine) & $\begin{array}{l}22-32 \\
34-52\end{array}$ & $\begin{array}{l}23 \\
23\end{array}$ & $\begin{array}{l}1.95 \\
1.96\end{array}$ & $\begin{array}{l}0.12 \\
0.11\end{array}$ & $\begin{array}{l}23 \\
23\end{array}$ & $\begin{array}{l}2 \cdot 78 \\
2 \cdot 67\end{array}$ & $\begin{array}{l}0.17 \\
0.15\end{array}$ & $\begin{array}{l}4 \cdot 008 \\
3 \cdot 697\end{array}$ & $\begin{array}{l}<0.001 \\
<0.001\end{array}$ \\
\hline Lead ( $\mu \mathrm{g} / \mathrm{g}$ creatinine) & $\begin{array}{l}22-32 \\
34-52\end{array}$ & $\begin{array}{l}23 \\
23\end{array}$ & $\begin{array}{c}13 \cdot 34 \\
15 \cdot 17\end{array}$ & $\begin{array}{l}0.98 \\
1.25\end{array}$ & $\begin{array}{l}23 \\
23\end{array}$ & $\begin{array}{l}29 \cdot 26 \\
27 \cdot 73\end{array}$ & $\begin{array}{l}2 \cdot 93 \\
2 \cdot 33\end{array}$ & $\begin{array}{l}5 \cdot 135 \\
4 \cdot 474\end{array}$ & $\begin{array}{l}<0.001 \\
<0.001\end{array}$ \\
\hline
\end{tabular}

industrial toxicants. There were many smokers both in the control and exposed groups.

In June 1977 we collected morning urines from normal and lead-exposed subjects. In each urine sample we determined the kallikrein activity (Porcelli and Croxatto, 1974), ALA (Davis et al., 1968) and lead (Cecchetti and Iannaccone, 1975). The values were related to the creatinine content of the urines.

Statistical evaluation of data was made by Student's $t$ test.

\section{Results and discussion}

Young exposed workers do not show a significant decrease in urinary kallikrein excretion (Table 2); on the other hand, the older group of lead workers show greatly reduced activity of the urinary enzyme compared with that of age-matched controls. The controls of different ages did not differ in urinary kallikrein activity.

Urinary ALA and lead are significantly increased in exposed subjects. There are no differences between the young and the old groups in mean urinary ALA and lead levels.

The most interesting finding of our study is that urinary kallikrein activity is altered only in the older lead workers, while urinary ALA increased independently of the age of the workers and was related to the inhibition of ALA dehydratase by lead (Berk et al., 1970). These data suggest that, with increasing age, the kidney becomes more susceptible to damage by lead than the erythropoietic system; moreover, the kidney may be damaged by an accumulation of cadmium (Lewis et al., 1972), an ubiquitous contaminant in the working environment, or by atherosclerosis.

Studies in vitro and on animals on controlled diets have demonstrated that essential minerals may protect against toxic effects of lead (Finelli et al., 1974; Finelli et al., 1975; Sandstead, 1976). It would therefore seem possible that in lead workers the essential metals in the diet, together with a genetic predisposition (Zinner et al., 1976), may also play an important part in determining the levels of urinary kallikrein activity.

The function of urinary kallikrein is not completely understood and we are therefore unable at present to evaluate the clinical importance of the reduction of urinary kallikrein excretion in lead-exposed humans. However, in these subjects, an alteration of an enzyme regulating the blood pressure must be considered to be more serious than the reversible modifications of haem synthesis.

The authors wish to express their gratitude to Dr V. N. Finelli and to Dr H. G. Petering for their helpful advice.

\section{References}

Berk, P. D., Tschudy, D. P., Shepley, L. A., Wagonner, J. G., and Berlin, N. I. (1970). Hematologic and biochemical studies in a case of lead poisoning. American Journal of Medicine, 48, 137-144.

Boscolo, P., Sacchettoni-Logroscino, G., and Bombardieri, G. (1977a). Alterazioni enzimatiche ed ultrastrutturali nei reni di ratti intossicati per un lungo periodo con piombo a basse dosi. Medicina del Lavoro, 68, 118-124.

Boscolo, P., Salimei, E., Adamo, A., and Porcelli, G. (1977b). Effects of environmental lead levels on the urinary kallikrein excretion of exposed workers. Life Sciences, 20, 1715 1722.

Cecchetti, G., Cerquiglini Monteriolo, S., Cotta-Ramusino, F., and De Sena, C. (1969). Application de la spéctrométrie de fluorescence $\mathrm{X}$ à la détermination de certains éléments pour le control de la pollution atmosphérique. $8^{\circ}$ Colloque sur l'Analyse de la Matière, Florence, September 15-19, pp. 207-211. Edited by G. Hanneman. Arti grafiche Crosignani: Milan.

Cecchetti, G., and Iannaccone, A. (1975). Determinazione della piomburia per spettrografia di emissione ottica con la tecnica del doppio arco. Atti del $2^{\circ}$ Convegno Nazionale di Igiene Industriale, Roma, December 15-16, 1975. Annali dell'Istituto Superiore di Sanità, 13, 367-377.

Cramér, K., and Dahlberg, L. (1966). Incidence of hypertension among lead workers. A follow-up study based on regular control over 20 years. British Journal of Industrial Medicine, 23, 101-104.

Cramér, K., Goyer, R. A., Jagenburg, R., and Wilson, M. H. (1974). Renal ultrastructure, renal function, and parameters of lead toxicity in workers with different periods of lead exposure. British Journal of Industrial Medicine, 31, 113-127. 
Croxatto, H. R., Roblero, J., Albertini, R., Corthorn, J., San Martin, M., and Porcelli, G. (1974). The kallikreinkinin system in renal hypertension. In Fogarty International Proceedings No. 27. Chemistry and Biology of the KallikreinKinin System in Health and Disease, Bethesda, October 2023, 1974, pp. 389-397. Edited by J. J. Pisano and K. F. Austen. US Government Printing Office, Washington, DC, USA.

Davis, J. R., Abrahams, R. H., Fishbein, W. I., and Fabrega, E. A. (1968). Urinary delta-aminolevulinic acid (ALA) levels in lead poisoning. Archives of Environmental Health, 17, 164-171.

Dingwall-Fordyce, I. and Lane, R. E. (1963). A follow-up study of lead workers. British Journal of Industrial Medicine, 20, 313-315.

Finelli, V. N., Klauder, D. S., Karaffa, M. A., and Petering, H. G. (1975). Interaction of zinc and lead on deltaaminolevulinate dehydratase. Biochemical and Biophysical Research Communications, 65, 303-311.

Finelli, V. N., Murthy, L., Peirano, W. B., and Petering, H. G. (1974). Delta-aminolevulinate dehydratase, a zincdependent enzyme. Biochemical and Biophysical Research Communications, 60, 1418-1424.

Galle, P., and Morel-Maroger, L. (1965). Les lésions rénales du saturnisme humain et expérimental. Nephron, 2, 273286.

Greco, A. V., Porcelli, G., Croxatto, H. R., Fedeli, G., and Ghirlanda, G. (1974). Ipertensione arteriosa e callicreina urinaria. Minerva Medica, 65, 3058-3062.

Iannaccone, A., Boscolo, P., Bertoli, E., and Bombardieri, G. (1974a). In vitro effects of lead on enzymatic activities of rabbit kidney mitochondria. Experientia, 30, 467-468.

Iannaccone, A., Porcelli, G., and Boscolo, P. (1975). Callicreina urinaria e rischio di saturnismo. Atti del $2^{\circ}$ Convegno Nazionale di Igiene Industriale, Roma, December 15-16, 1975. Annali dell'Istituto Superiore di Sanità, 13, 409-417.

Iannaccone, A., Porcelli, G., Boscolo, P., and Ranieri, M. (1974b). Urinary kallikrein excretion in lead intoxication. In Fogarty International Proceedings No. 27. Chemistry and Biology of the Kallikrein-Kinin System in Health and Disease. Bethesda, October 20-23, 1974, p. 437. Edited by J. J. Pisano and K. F. Austen. US Government Printing Offlce, Washington DC, USA.

Lane, R. E. (1949). The care of the lead worker. British
Journal of Industrial Medicine, 6, 125-143.

Lewis, G. P., Jusko, W. J., Coughlin, L. L., and Stuart, H. (1972). Contribution of cigarette smoking to cadmium accumulation in man. Lancet, 1, 291-292.

Lilis, R., Gavrilescu, N., Nestorescu, B., Dumitriu, C., and Roventa, A. (1968). Nephropathy in chronic lead poisoning. British Journal of Industrial Medicine, 25, 196-202.

Margolius, H. S., Geller, R., Pisano, J. J., and Sjoerdsma, A. (1971). Altered urinary kallikrein excretion in human hypertension. Lancet, 2, 1063-1065.

Margolius, H. S., Horwitz, D., Pisano, J. J., and Keiser, H. R. (1974). Urinary kallikrein excretion in hypertensive man. Relationships to sodium intake and sodium-retaining steroids. Circulation Research, 35, 820-825.

McGiff, J. C., Itskovitz, H. D., Terragno, A., and Y-Kwong, P. (1976). Modulation and mediation of the action of the renal kallikrein-kinin system by prostaglandins. Federation Proceedings, 35, 175-180.

Nustad, K , Vaaje, K., and Pierce, J. V. (1975). Synthesis of kallikrein by rat kidney slices. British Journal of Pharmacology, 53, 229-234.

Porcelli, G., and Croxatto, H. R. (1974). Direct UV spectrophotometric measurement of urinary kallikrein. Biochemistry and Experimental Biology, 11, 263-266.

Rhyne, B. C., and Goyer, R. A. (1971). Cytochrome content of kidney mitochondria in experimental lead poisoning. Experimental Molecular Pathology, 14, 386-391.

Roblero, J., Croxatto, H. R., Garcia, R., Corthorn, J., and De Vito, E. (1973). Kininogenase activity in urine and perfusion fluid of isolated rat kidney. Acta Phisiologica Latino Americana, 23, 566-568.

Sandstead, H. H. (1976). Interactions of cadmium and lead with essential minerals. In Effects and Dose-Response Relationships of Toxic Metals, pp. 511-526. Edited by G. F. Nordberg. Elsevier: Amsterdam.

Sandstead, H. H., Michelakis, A. M., and Temple, T. E. (1970). Lead intoxication. Its effect on the renin-aldosterone response to sodium deprivation. Archives of Environmental Health, 20, 356-363.

Zinner, S. H., Margolius, H. S., Rosner, B., Keiser, H. R., and Kass, E. H. (1976). Familial aggregation of urinary kallikrein concentration in childhood: relation to blood pressure, race and urinary electrolytes. American Journal of Epidemiology, 104, 124-132. 